JEFFREY W. RIEMER is Associate Professor of Sociology at Wichita State University. His current research interest is work in the moral order.

DEBORAH A. WILLSIE graduated, with a B.A. degree in Sociology and Social Work from Wichita State University, June 1980. She is currently doing graduate work at Syracuse University in New York.

RENEE M. ZIMMERMAN is currently a graduate student at Kansas University. She received a B.A. in both Psychology and Sociology in 1977 and completed her work at Wichita State University with a M.A. degree in Sociology. Renee is concentrating her research efforts in medical sociology, gerontology, and issues of death and dying.

\section{IN PRAISE OF MOSCA AND MICHELS}

\author{
Gerhard Lenski \\ University of North Carolina-Chapel Hill
}

Mid-American Review of Sociology, 1980, Vol. V, No, 2:1-12

Genealogy is a selective art. When tracing ancestry, genealogists usually focus attention on their more illustrious forebears, while ignoring others whose careers seem less admirable.

Sociological genealogists are also highly selective. When teaching or writing about the history of our discipline, the treatment of our many intellectual forebears is usually quite uneven. Some are singled out for high praise, and become almost godlike figures, while others receive much more modest treatment or are ignored altogether. In recent years, it has been fashionable to laud especially the contributions of Weber, Marx, and Durkheim. In contrast, many others, such as Malthus, Comte, Spencer, and Sumner, who were influential and important figures in their own day and who offer alterative models for the discipline, receive much less attention, and still others, such as Mosca and Michels, are virtually ignored.

The reasons for such varied treatment are certainly understandable. Academic genealogy is an important part of the intellectual socialization process, and it is important to inculcate in each new generation of students the virtues we perceive in influential members of generations past. Conversely, we need to beware of giving undue attention to scholars of the past who may, by word or deed, lead younger scholars from the path of virtue. Elitist theorists, Mosca and Michels, seem to be regarded in this latter category. Their theories are reputed to have a conservative bias and the lives of both men were tainted by association with Italian fascism. Given the political preferences of the great majority of contemporary sociologists, this has been the kiss of death. I believe, however, that Mosca and Michels deserve better at our hands and that the widespread neglect of their work has handicapped the development of current theory in ways that have proven unfortunate. 


\section{TWO TYPES OF ELITIST THEORY}

Before considering the work of Mosca and Michels, it may be helpful to take note of an important distinction between two types of elitist theory. On the one hand, there is normative elitism; on the other, there is analytical elitism. The boundary between them often seems blurred, because scholars often fail to dif ferentiate between the two types of elitist theory in their writings. But the distinction is a crucial one, and one that should not be ignored.

Elitist theories of the normative variety are those which assert that certain people are morally, intellectually, or otherwise superior and therefore entitled to govern. Plato (n.d.:203) offers a classic example of this type of theory in The Republic. His central thesis there is summed up in the oft-quoted statement, "Until philosophers are kings, or the kings and princes of this world have the spirit and power of philosophy, and political greatness and wisdom are combined, and these commoner natures who pursue either to the exclusion of the other are compelled to stand aside, cities will never have rest from their evils."

Elitist theories of the analytical variety, in contrast, are not concerned with what ought to be, but with what is-how political systems actually function. Thus, Gaetano Mosca (1896:50) asserts that "In all societies. . two classes of people appear-a class that rules and a class that is ruled." Or, Robert Michels (1911:401) tells us in his famous Iron Law of Oligarche that "Who says organization says oligarchy."

Basically, Mosca and Michels do not address the moral question of what ought to be, but focus on the scientific question of what is, and the related question of why such patterns prevail. In fact, it should be noted that in his famous volume, Political Parties, Michels (1911:408) made his democratic sympathies clear on more than one occasion. For example, in the closing pages of the book, he wrote, "... the more humanity comes to recognize the advantages which democracy, however imperfect, presents over aristocracy, even at its best, the less likely is it that a recognition of the defects of democracy will provoke a return to aristocracy." He then went on to say that the defects of democracy "inhere in its inability to get rid of its aristocratic scoriae."

The possibility of a disjuncture between normative and analytical elitism is an important point, which many have been slow to recognize. One can be an analytical elitist without being a normative elitist, and vice versa. In fact, I think that there is a definite tendency in this direction among the handful of social scientists who have espoused analytical elitist theory. Be that as it may, however, when I praise elitist theory, it is the theory or theories of the analytical elitists.

\section{WHY PRAISE MOSCA AND MICHELS?}

Why do we need elitist theory? What have the analytical elitists to offer that Marx, Weber, Durkheim, Parsons, or our other theoretical luminaries do not already provide?

There are various answers to this question, but I would argue that one of the best is to say that the analytical elitists have a theory with remarkable powers of prediction. This is what we always say we want in sociology, and this is what this school of theorists can provide.

Let me offer two examples-one prediction that is a bit blurred and fuzzy by Michels, another that is much more sharply etched by Mosca. Writing in 1911, six years before the Russian Revolution and thirty-eight years before the Chinese, Michels (1911:391) asserted, "The socialists may conquer, but not socialism, which would perish in the moment of its adherents' triumph." This remarkably prophetic statement is a kind of summing up of a lengthy analysis in which he argues (1911:386) that "The problem of socialism is not merely a problem in economics... [it] is also an administrative problem, a problem of democracy."

In this analysis, Michels is following the lead of Mosca, who discussed the same problem fifteen years earlier-twenty years before the first successful socialist revolution. In it, Mosca sought to predict what a socialist society would be like. It should be noted that in this prediction he was attempting to describe the characteristics of a phenomenon which did not yet exist, a type 
of prediction that is far more difficult than the type of prediction found in most sociological journal articles today. Mosca (1896: 284-5) wrote,

Communist and collectivist societies would beyond any doubt be managed by officials. Let us assume, for the best case, that in accord with the norms of social democracy, they would be elected exclusively by universal suffrage. We have already seen how political powers function when they are exclusively, or almost exclusively, in the hands of so-called 'people's choices.' We know that majorities have only the mere right of choosing between a few possible candidates, and that they cannot, therefore, exercise over them anything more than a spasmodic, limited and often ineffective control. We know that the selection of candidates is itself almost always the work of organized minorities who specialize by taste or vocation in politics and electioneering, or else the work of caucuses and committees whose interests are often at variance with the interests of the majority. We know the ruses that the worst of them use to nullify or falsify the verdicts of the polls to their advantage. We know the lies they tell, the promises they make and betray and the violence they do in order to win or wheedle votes.

But communists and collectivists may object that all this happens because of the present capitalistic organization of society, because great landowners and owners of great fortunes now have a thousand means, direct or indirect, for influencing and buying the votes of the poor, and that they use them to make universal suffrage a sham and assure political dominion to themselves. To avoid these drawbacks if for nothing else, they might argue, we should change the social order radically.

Those who reason in that manner forget the most important detail in the problem. They forget that even in societies organized as they propose there would still be those who manage the public wealth and then the great mass of those who are managed. Now the latter would have to be satisfied with the share that was allotted to them. The administrators of the social republic would also be its political heads, and they would undoubtedly be far more powerful than the ministers and millionaires we know today. If a man has the power to constrain others to a given task, and to fix the allotments of material enjoyments and moral satisfactions that will be the recompense for the performance of the task, he will always be a despot over his fellows, however much he may be curbed by laws and regulations, and he will always be able to sway their consciences and their wills to his advantage.

All the lying, all the baseness, all the violence, all the fraud that we see in political life at present are used in intrigues to win votes, in order to get ahead in public office or simply in order to make money fast by unscrupulous means. Under a collectivist system everything of that sort would be aimed at controlling the administration of the collectivist enterprise. There would be one goal for the greedy, the shrewd and the violent, one direction for the cabals and the cliques which would form to the detriment of the gentler, the fairer, the more sincere. Such differences as there would be would all be in favor of our present society; for to destroy the multiplicity of political forces, that variety of ways and means by which social importance and all possibility of reciprocal balancing and control. As things are today, the office clerk can at least laugh at the millionaire. A good workman who can earn a decent living with his own hands has nothing to fear from the politician, the department secretary, the deputy or the minister. Anyone who has a respectable position as the owner to a piece of land, as a businessman, as a member of a profession, can hold his head high before all the powers of the state and all the great landlords and financial barons in the world. Under collectivism, everyone will have to kowtow to the men in the government. They alone can dispense favor, bread, the joy and sorrow of life.

What we have here is a remarkable anticipation of Milovan Djilas' (1953) conclusion, based on his experience with postrevolutionary Yugoslavia and his observations of the Soviet Union, that Marxist regimes have given birth to a new class - a new class that controls the means of production and derives from that 
fact enormous power and substantial privilege. And Djilas is not alone in his analysis of the realities of socialist societies. Numerous other Marxists and ex-Marxists have come to much the same conclusion (e.g., Juron and Modzelewski, 1965; Hegudus, 1977; Huberman and Sweezey, 1967). More recently, a growing body of evidence from other socialist societies, such as China, Cuba, Vietnam, North Korea, and Cambodia, provide further support for Mosca's grim prediction.

There have probably been few true predictions (i.e., excluding retrodictions and predictions of occurrences of prior patterns) in the history of social science more on target than this prediction of Mosca. Surely it compares favorably with Marx's predictions of revolutions in the leading centers of capitalism spearheaded by a united proletariat, or his prediction of the emergence of the new socialist man following the revolution. I make this comparison not to disparage Marx, but rather to praise Mosca and his theory.

I should also note here that in many ways Marx, himself, can be claimed as a quasi-elitist. For during the great span of history that lies between the era of primitive communism and the era of modern communism, or socialism, that follows the proletarian revolution, he sees society in terms remarkably like those of Mosca-"a class that rules and class that is ruled." Marx calls them "the oppressors" and "the oppressed," but those pejorative labels do not hide the fact that he sees the oppressors playing a socially necessary and unavoidable role. In fact, he goes further and even praises one set of oppressors, the bourgeoisie, for expanding the forces of production and thereby laying the foundation for improved conditions of life in the future. If Mosca proved better at prediction than Marx, it may only be because Marx's ideals betrayed him and led him to abandon his elitist perspective on the post-revolutionary era.

Returning to the more successful predictions of Mosca and Michels, it is important to emphasize that these were not just lucky shots in the dark. On the contrary, they were thoroughly grounded in elitist theory and research. This can be seen best in Michel's analysis of the socialist parties of western Europe in the pre-World War I era and the reasons for their inability to create true democracy and equality within their own ranks. In effect, he argued that if socialist party organizations themselves have evolved into undemocratic oligarchies, how can the socialists hope to prevent this in the larger society where large numbers of people do not share their ideals.

In his analysis of the socialist movement, Michels concludes that there are three basic sets of forces that give rise to oligarchy. First, there are the needs of the organization itself. When an organization is successful, it grows in size and complexity. This leads to the necessity of a division of labor and the creation of specialized leadership roles. In principle, the leader is merely the agent of the members and bound by their instructions, but as the organization grows, this control becomes "purely fictitious" p.34). More than that, "Every organ of a group, brought into existence through the need for the division of labor, creates for itself... interests peculiar to itself. The existence of these special interests involves a necessary conflict with the interests of the group" (p. 389).

This leads Michels to a consideration of the needs or interests of the leaders. Lord Acton, the famous Catholic critic of the doctrine of papal infallibility once wrote, "Power tends to corrupt; absolute power corrupts absolutely." Michels obviously shares this view, and one of his chapters in Political Parties is entitled, "The Psychological Metamorphosis of Leaders." Here he argues that the exercise of power makes men vain-it makes them believe that they are indispensible to the organization. And, ultimately, it leads them to identify their own personal interests with those of the organization. Thus, an attack on themselves or their policies becomes an attack on the party or even the sacred principles of socialism. Paraphrasing Louis XIV, Michels (1911:227) says they come to believe, "Le Parti c'est moi." Finally, Michels turns to a consideration of the needs and desires of the rank and file within the party. Most of them, he argues, are too busy with other concerns to offer the leaders any serious challenge (and Mosca would add, they are too unorganized). The younger men, Michels says, are too busy with girlfriends, and older men are too busy with the economic needs of their families. 
Furthermore, the masses need heroes and they do not really understand the complex process of decision-making within the party.

As a result of the interaction of these three sets of forces, oligarchy becomes inevitable. This leads Michels to his Iron Law of Oligarchy and to the statement that "The problem of socialism is not merely a problem of economics. . [ [it] is also an administrative problem." This is a conclusion that has come to be shared in more recent years by a considerable number of sociologists and socialists in eastern Europe in more recent years, even when they do not cite Michels.

\section{IS ELITIST THEORY A COUNSEL OF DESPAIR?}

One criticism sometimes leveled at elitist theory is that it offers a counsel of despair. I believe, however, that this view is based on a serious misreading of what Mosca and Michels have written. Michels (1911:404-8), for example, said that the great task of education was to raise the intellectual level of the masses "so that they may be enabled, within the limits of what is possible, to counteract the oligarchical tendencies in the workingclass movement." Elsewhere, he wrote, "Nothing but a serene and frank examination of the oligarchical dangers of democracy will enable us to minimize these dangers." Or, finally, he asserts, even more bluntly "... it would be erroneous to conclude that we should renounce all endeavors to ascertain the limits which may be imposed upon the powers exercised over the individual by oligarchies. It would be an error to abandon the desperate enterprise of endeavoring to discover a social order which will render possible the complete realization of the ideal of popular sovereignty."

In short, as I read Michels, and many of the other analytical elitists as well, they counsel a healthy combination of realism and idealism, rather than the single-minded idealism that characterizes so many modern political movements and which threatens, at times, the intellectual integrity of sociology and some of the other social sciences.

\section{WHAT IF?}

Turning to contemporary sociology, we must ask ourselves how it might be altered if analytical elitist theory came to play a more prominent role in writing and research. How would things change in our discipline if we paid more attention of Michels and Mosca, and somewhat less to Durkheim, Parsons, and other currently more popular theorists?

I do not have a crystal ball to provide an answer to this question, but there are some changes 1 would expect. First, the field of stratification would not be dominated as it has been recently by statistical studies of status attainment. Instead, much of the energy we now devote to the study of the petty successes and failures of the mass of little people would be focused on the lives and activities of political elites. We would have not just a handful of studies of community power, but scores of them, In other words, we would have shift of attention from the mass to the elites and from prestige to power. Studies like those of Floyd Hunter $(1953,1959,1980)$ and C. Wright Mills (1959) would be at least as fashionable as studies modeled on Blau and Duncan, Hauser, and Sewell. Furthermore, we would not be leaving the study of the rich and the powerful to nonsociologists, such as Ferdinand Lundberg (1978) and G. William Domhoff (1967, $1970,1978)$, or the study of such an important subject as tax politics to economists, such as Pechman and Okner (1974). (I say this not to disparage the work of these nonsociologists, but rather to urge their emulation.)

Second, elitist theory contains the germs of a model of the American political system that might sharpen our understanding of how it works-not just on election day, but on the other 729 days of each biennium. Basically, this would be a model of the mass versus the elite, with each controlling one vital resource: votes on the one hand, money on the other. Mosca also draws attention to the role of organization as a potential resource available to both sides-but more readily available to elites because of their smaller numbers. In short, building on elitist theory, we would begin to see our American political system as a rather intriguing institutional structure that responds to both the worm's 
eye view of society of the masses and the bird's eye view of the elite-each incomplete in itself. Or, to put it another way, our system, as it has evolved, taps both the masses' personal experience with the defects and shortcomings of the system and the elite's more systemic and longer-range perspectives. Both of these, I suspect, are necessary inputs in any healthy political system.

A third benefit which we might expect from greater attention to elitist theory would be a more realistic set of assumptions concerning human nature. Modern sociology, like modern socialism, is a product of the Enlightenment and transmits from generation to generation, as part of its unexamined heritage of assumptions, an eighteenth century view of human nature. We build most of our theories and predictions on the dubious assumption that humans are naturally generous and unselfish and that it is only faulty social institutions that make them act otherwise. Thus, criminologists routinely blame the system, rarely the criminal, and students of our educational system blame the schools, not the students.

Marxists tell us that if only we get rid of the system of private property we will see a new and better kind of person emerge-one who puts the good of society ahead of his or her own personal interests. But, somehow, this has not happened-not in the Soviet Union, not in East Germany, not in China, not in Vietnam, not in Cuba, nowhere! The sorry truth of the matter seems to be that our primate genetic heritage makes us very individualistic animals, far more so than the social insects, for example, for whom cooperation comes naturally. Our geneticallygrounded individualism goes hand in hand with our immense capacity for learning, a highly individuated and individuating experience. Elitist theory takes the self-seeking nature of humans as a given and seeks to work from there.

This leads to a fourth benefit which we can reasonably expect to derive from greater attention to elitist theory. It can serve as a healthy antidote against the intrusion into our discipline of powerful and compelling utopian ideologies that are bound to develop from time to time. The nineteen-sixties and -seventies proved how vulnerable sociology is. Durkheim, Weber, Parsons, and none of the rest of our honored theorists provided any really effective defense against the new utopianism that promised participatory democracy and social justice for all and came dangerously close to creating instead a powerful new police state. Elitist theory, in contrast, encourages us to study the great social experiments that have been carried out in the twentieth century in a score of nations under the leadership of utopian-minded elites. It encourages us to study these experiments and to learn from both their successes and their failures. It encourages us also to compare the realities of these societies (rather than their ideals) with the realities of our own. And when we do this, we may well conclude with Michels that "The defects inherent in democracy are obvious. It is none the less true that as a form of social like we must choose democracy as the least of evils."

\section{CONCLUSION}

Let me sum up by saying that analytical elitist theory, as represented by Mosca and Michels, has much to commend it, especially to a discipline that aspires to develop a scientific analysis of human societies. And if $I$ have not persuaded all who read this to become instant elitists, I hope that I have at least persuaded some to read, or reread, Robert Michels' Political Parties, and Gaetano Mosca's, The Ruling Class, for even when the reader disagrees with these authors, he finds their arguments stimulating and thought-provoking.

\section{REFERENCES}

Djilas, Milovan

[1953] The New Class. New York: Praeger.

Domhoff, G. William

1967 Who Rules America? Englewood Cliffs: Prentice Hall

1970 The Higher Circles. New York: Random House.

1978 Who Really Rules? Santa Monica: Goodyear. 


\section{SOCIO-STRUCTURAL ANALYSIS OF IMMIGRANT WORKER MINORITIES: THE CASE OF WEST-GERMANY*}

\author{
Friedrich Heckmanm \\ Sozialwissenschaftliches Institut der Universität \\ Erlangen-Nümberg
}

Mid-American Review of Sociology, 1980, Vol. V, No. 2:13-30

\section{INTRODUCTION}

In purely economic terms the Federal Republic of Germany has been an immigrant society from its very beginning. Till 1961, 13.34 Mill. people emigrated to West Germany, primarily from areas of the former state territory and the German Democratic Republic ( $c f$. Wieduwilt and Jürgens, 1976:138). However, these migrants and fugitives had been of German nationality. True immigration began only after 1961 when the German Democratic Republic closed its border and internal demographic and sociostructural processes decreased the West German work force. ${ }^{1}$ The growing industry found new markets in southern Europe for the recruitment of labor. The number of foreign employed-a very large majority of them workers-rose from 0.5 Mill. in 1961 or 2.5 percent of the total work force to a high of $2.6 \mathrm{Mill}$. in 1973 or 11.9 percent of the total work force; due to the economic crisis it has dropped to around 2 Mill. or a little under 10 percent of the total work force by now.

This paper has two major intentions: 1) to demonstrate that West Germany has become an immigrant society in a truely sociological sense, that the so-called "guest-workers" and their families rather than being migratory workers have become part of the social structure; 2) to advance a socio-structural concept for the analysis of immigrant worker minorities.

*Paper delivered to the joint session of the ISA Research Committee on Migration and the Research Committee on Ethnic, Race, and Minority Relations at the 9th World Congress of Sociology in Uppsala, Sweden, 14 . 19th August, 1978. 